\title{
Enhancement of lesion-induced mouse killing by preoperative gentling
}

\author{
D. J. ALBERT, G. L. CHEW, A. TOBANI, and M. L. WALSH \\ University of British Columbia, Vancouver, British Columbia V6T 1W5, Canada
}

\begin{abstract}
Rats that did not spontaneously kill mice were either gentled or not gentled for $10 \mathrm{~min} /$ day for 7 days. Animals from both the gentled and nongentled groups were then subjected to a lesion of the lateral septum, a lesion ventral to the anterior septum, or a sham lesion. When tested at $48 \mathrm{~h}$ postoperatively, the frequency of killing in the gentled groups was $70 \%$ to $90 \%$ for lesioned animals, about double that in the ungentled lesion groups. There was no effect of gentling on killing by the unlesioned groups, both of which had less than $15 \%$ killers. The relationship of the facilitation of mouse killing caused by gentling to a decrease of fear is discussed.
\end{abstract}

Mouse killing by rats is increasingly being studied as an instance of agonistic behavior. The frequency with which it occurs spontaneously varies considerably from one strain to another (Eichelman, 1980; Latham \& Thorne, 1974) and also with different groups of rats obtained from the same colony (Albert, Note 1). Substantial behavioral differences between spontaneous killer rats and nonkiller rats have not yet been found (Knutson \& Hynan, 1973; Novakova, Flanders, \& Sandritter, 1974; Vergnes, Boehrer, \& Karli, 1974).

Mouse killing can be induced by brain lesions, but again, the success rate varies considerably even in animals in which the lesions are similar (Albert \& Brayley, 1979; Albert, Nanji, \& Chew, 1981; Eclancher \& Karli, 1980; Malick, 1970; Panksepp, 1971). Although a considerable amount of this variation may be the result of some differences in the size, shape, and location of lesions, these do not account for all of the behavioral variation.

The object of the present experiment was to demonstrate that preoperative gentling is a variable that influences the frequency with which lesions of the lateral septum or of the region ventral to the anterior septum induce mouse killing. The significance of gentling as a variable was suggested when we noticed that the frequency of killing obtained in an experiment in which the rats had inadvertently received a small amount of handling preoperatively (Albert \& Brayley, 1979) was substantially higher than that obtained in another experiment in which they did not (Albert, Nanji, \& Chew, 1981).

This work was supported in part by a grant from the National Science and Engineering Research Council of Canada. G. L. Chew is now at Carleton University. Requests for reprints should be sent to D. J. Albert, Department of Psychology, University of British Columbia, Vancouver, British Columbia B6T 1W5, Canada.

\section{METHOD}

The subjects were 73 rats weighing $300-400 \mathrm{~g}$ at the beginning of the experiment (from Canadian Breeding Farms and Laboratories). Prior to the experiment, they were housed in group cages. At the beginning of the experiment, each animal was put into a single-animal cage. Twenty-four hours later, each rat was screened for mouse killing by placing an adult albino mouse in its cage for $15 \mathrm{~min}$. The 59 animals that did not kill continued in the experiment. Following the test for spontaneous mouse killing, approximately half of the animals were given daily gentling and the other half were not. The gentling consisted of handling, stroking, and picking up and putting down. This was done for a 10 min period each day for 7 days. At the end of the 7 days of gentling, gentled and nongentled rats were given lesions of the lateral septum, lesions ventral to the anterior septum, or sham lesions. The lesions of the lateral septum were centered at $2.0 \mathrm{~mm}$ rostral to bregma, $.7 \mathrm{~mm}$ lateral to the midline, and $5.5 \mathrm{~mm}$ ventral to the cortical surface (mouth bar $5.0 \mathrm{~mm}$ above the interaural line; lesioning current $3.0 \mathrm{~mA}, 20 \mathrm{sec}$ ). The lesions of the region ventral to the anterior septum were centered at $2.9 \mathrm{~mm}$ rostral to bregma, $1.0 \mathrm{~mm}$ lateral, and $7.0 \mathrm{~mm}$ ventral $(2.0 \mathrm{~mA}, 25 \mathrm{sec})$. Shamlesioned control animals had holes drilled in their skulls, but the electrode was not lowered into the brain.

Reactivity to the experimenter was tested on Day 2 in the manner described in several recent reports (Albert \& Brayley, 1979; Albert \& Richmond, 1975; Albert, Nanji, \& Chew, 1981).

Mouse killing was tested at 3 days postoperatively. Testing was done in the living cage of the test animal and consisted of gently dropping the adult albino mouse into the cage. The mouse was left in the cage for a maximum of $15 \mathrm{~min}$.

Following testing, each rat was killed and its brain was placed in formol-saline. The brains were later sectioned in a cryostat and stained with cresyl violet.

\section{RESULTS}

Preoperative gentling doubled the frequency of mouse killing in rats with lesions of the lateral septum or of the region ventral to the anterior septum (Table 1). Although the percentage increase in mouse killing produced by the preoperative gentling was large, the differences between gentled and nongentled conditions 
were significant only if the two lesion groups were combined $\left(\chi^{2}=6.4, p<.02\right)$.

When compared with the respective gentled or nongentled sham-operated control group, the frequency of killing in rats with lesions ventral to the anterior septum or of the lateral septum were significantly greater in the groups that were gentled $\left(\chi^{2}=12.7, p<.01\right.$; $\left.\chi^{2}=8.0, p<.01\right)$. The increases in mouse killing did not reach statistical significance in the groups that were not gentled.

Gentling did not increase the frequency of mouse killing in the sham-operated rats.

The results of the reactivity test were discarded because of irregularities in the testing procedure. Results of a subsequent experiment examining reactivity following preoperative gentling are reported elsewhere (Albert, Chew, Tobani, Walsh, Lee, \& Ryan, 1981).

\section{Histology}

The animals whose data are included in Table $1 \mathrm{had}$ lesions similar to those shown in Figure 1. Evaluation of the histological material was done blind and resulted in exclusion of the results from two gentled and two nongentled animals with lesions ventral to the anterior septum. The excluded animals had lesions that were misplaced posteriorly or were too small.

\section{DISCUSSION}

Preoperative gentling does increase the frequency with which lesions of the lateral septum or of the region ventral to the anterior septum induce mouse killing. The killing frequencies obtained in the gentled and lesioned animals are comparable to the highest frequencies we have obtained with such lesions (Albert \& Brayley, 1979). The killing frequencies of the nongentled groups are slightly lower than those we have obtained with another experiment (Albert, Nanji, \& Chew, 1981).

The reason for the influence of gentling on lesion-induced mouse killing is not obvious. It initially seemed likely that the gentling might facilitate killing by attenuating the hyperreactivity that is normally induced by the lesions. However, a subsequent experiment has demonstrated that the gentling does not attenuate the lesion-induced reactivity (Albert, Chew, Tobani, Walsh, Lee, \& Ryan, 1981). Another possibility is that preoperative gentling decreases fear at the postoperative test. It is known that lesioned animals are less likely to kill a mouse in a novel environment (Albert \& Brayley, 1979). We have generally assumed that this is due to the fear aroused by the novel environment. It is possible that the gentling has an effect in reducing fear even when the rat is tested in its home cage. This would make home-cage killing more likely to occur.

Table 1

\begin{tabular}{lc}
\hline Group & Proportion Killing Mouse \\
\hline Gentled-AV & $8 / 9^{*}$ \\
Ungentled-AV & $4 / 9$ \\
Gentled-LS & $5 / 7^{*}>\mathrm{p}<.02$ \\
Ungentled-LS & $2 / 7$ \\
Gentled-Sham & $1 / 11$ \\
Ungentled-Sham & $2 / 16$ \\
\hline
\end{tabular}

*Significantly different from gentled sham $\left(\mathrm{x}^{2}\right), p<.01$.
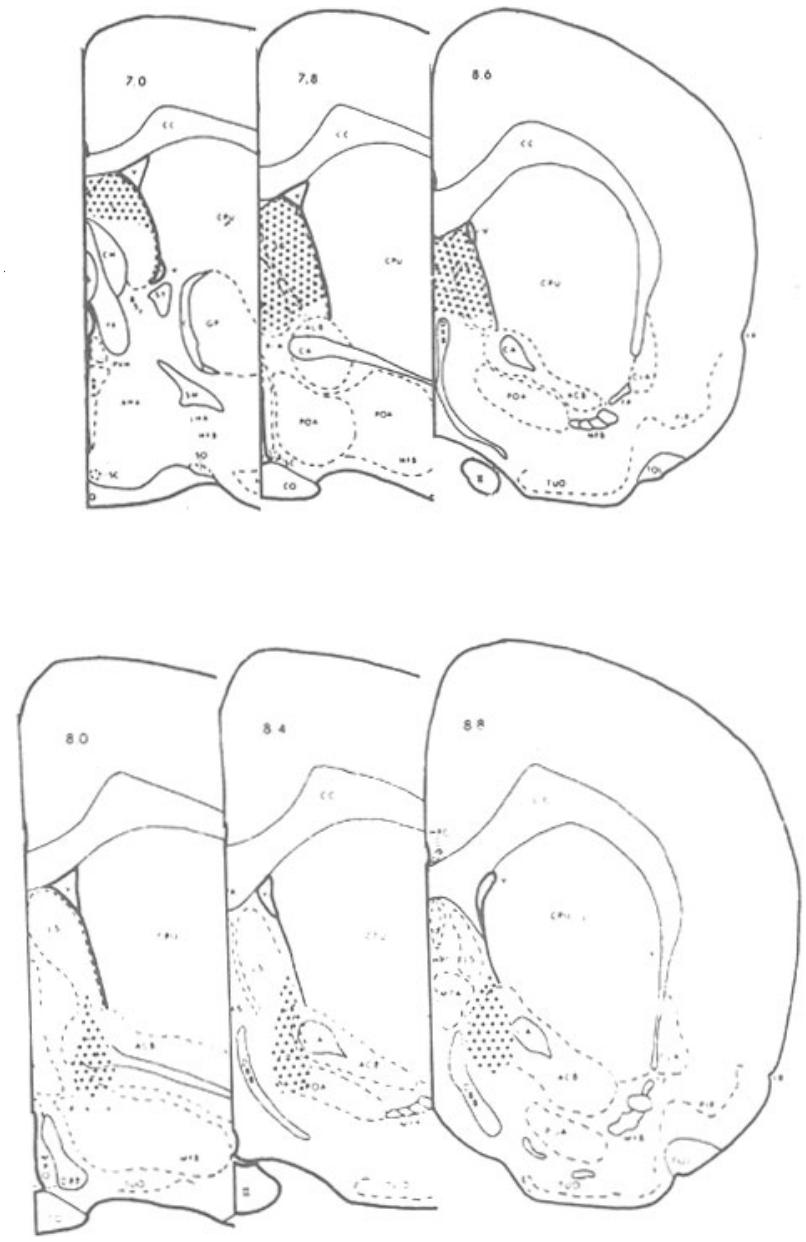

Figure 1. The stippled areas indicate the tissue destroyed in animals with lesions of the septum (top) or of the region ventral to the anterior septum (bottom).

It is interesting to note the similarity between the facilitation of mouse killing produced by amygdala lesions and that caused by gentling. Neither is sufficient to induce mouse killing alone, but each is effective when used in conjunction with another facilitating manipulation (Karli, Vergnes, Eclancher, \& Penot, 1977; Vergnes, 1975, 1976). The common effect of both gentling and amygdala lesions may be mediated by a reduction in fear.

\section{REFERENCE NOTE}

1. Albert, D. J. Unpublished observations, 1981.

\section{REFERENCES}

Albert, D. J., \& Brayley, K. N. Mouse killing and hyperreactivity following lesions of the medial hypothalamus, the lateral septum, the bed nucleus of the stria terminalis, or the region ventral to the anterior septum. Physiology \& Behavior, $1979,23,439-443$.

Albert, D. J., Chew, G. L., Tobani, A., Walsh, M. L., Lee, C. Y. S., \& RYAN, J. Preoperative handling does not attenuate septal-lesion induced hyperreactivity. Physiology \& Behavior, 1981, 27, 387-389. 
Albert, D. J., Nanji, N., \& Chew, G. L. Structures posterior to the olfactory bulb which are responsible for the mouse killing and hyperreactivity following large lesions of the olfactory bulb. Physiology \& Behavior, 1981, 26, 395-399.

Albert, D. J., \& Richmond, S. E. Septal hyperreactivity: A comparison of lesions within and adjacent to the septum. Physiology \& Behavior, 1975, 15, 339-347.

Eclancher, F., \& Karli, P. Septal damage in infant and adult rats: Effects on activity, emotionality and muricide. Aggressive Behavior, 1980, 5, 388-415.

Eichelman, B. Variability in rat irritable and predatory aggression. Behavioral and Neural Biology, 1980, 29, 498-505.

Karli, P., Vergnes, M., Eclancher, F., \& Penot, C. Involvement of amygdala in inhibitory control over aggression in the rat: A synopsis. Aggressive Behavior, 1977, 3, 157-162.

Knutson, J. F., \& Hynan, M. T. Predatory aggression and irritable aggression: Shock-induced fighting in mouse killing rats. Physiology \& Behavior, 1973, 11, 113-115.

LAtham, E. E., \& Thorne, B. M. Septal damage and muricide: Effects of strain and handling. Physiology \& Behavior, 1974, $12,521-526$
MALICK, J. B. A behavioral comparison of three lesion-induced models of aggression in the rat. Physiology \& Behavior, 1970 , $5,679-681$.

Novakova, V., Flandera, V., \& Sandritter, W. Aggressive rats: Some properties of learning, memory, and of the limbic system. Pharmacology, Biochemistry and Behavior, 1974, 2, 729-733.

Pankse PP, J. Effect of hypothalamic lesions on mouse killing and shock-induced fighting in rats. Physiology \& Behavior, 1971, 6, 311-316.

Vergnes, M. Déclenchement de réactions d'agression interspecifique après lesion amygdalienne chez le rat. Physiology \& Behavior, 1975, 14, 271-276.

Vergnes, M. Controle amygdalien de comportements d'agression chez le rat. Physiology \& Behavior, 1976, 17, 439-444.

Vergnes, M., Boehrer, A., \& Karli, P. Intraspecific aggressiveness and reactivity in mouse-killing and nonkilling rats: Compared effects of olfactory bulb removal and raphe lesions. Aggressive Behavior, 1974, 1, 1-16.

(Received for publication August 24, 1981.) 